\title{
Testimonial Exclusions and Religious Freedom in Early America - CORRIGENDUM
}

\author{
JUD CAMPBELL
}

doi: $10.1017 /$ S0738248018000482, Published by Cambridge University Press, 18 March 2019

The corresponding author email address was incorrect for the above article. ${ }^{1}$ The correct email address is jcampbe4@richmond.edu.

The email address has been updated online.

\section{Reference}

1. Jud Campbell, "Testimonial Exclusions and Religious Freedom in Early America," Law and History Review. doi:10.1017/S0738248018000482. 